\section{The Role of the Museums in Lifelong Learning for Adults}

Elham Salah Eldin Mohamed Aly, Aly Omar Abdallah and Guido Fackler

\section{Abstract}

Museums have a deep impact on lifelong learning process where they are active tools to enhance social inclusion, active citizenship, and personal development. The biggest argument that raises doubt over lifelong learning process in museums is the quality of the experiences presented by the museums. At the beginning of the 19th century, new ideas developed and museums were used for educating and enlightening the general public in order to civilize people and make the societies better ${ }^{1}$ Thereby, hey were given the role of serving as one of the societies" main cultural hister apes

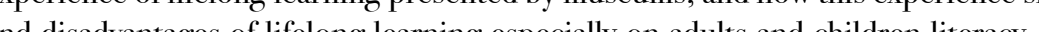

\section{Key Words}

Display - storytelling- perspective- visitors' experience - lifelong learning - interpretation

\section{Introduction}

The lifelong learning meaning, attitudes and motivations help to use it for set up various activities of lifelong learning programs in Sohag Museum for social development. Museums today are in competition with other culture institutions such as cinemas, theatres, libraries, cafes and shopping centers. Museums can be all of those and turn on their galleries to be puppet theatres, cinemas, schools, universities and their collection would be the actors, actresses, who are active both verbally and emotionally. Museums are different in teaching and educating ways as they are more attractive and interactive. Collections' interpretation and storytelling bring objects back to life; talking scenes are thus offering more forms of knowledge for their visitors' needs. integration, life skills, and employment.

The main objective of this article is to highlight lifelong learning, educational programs and community engagement and its impact on Sohag for social development. It concentrates on Sohag's community, the needs, and interests of all Sohag communitie

\section{Museums for lifelong learning}

The concept of lifelong learning is connected firmly to museums. In 1926, the American adult educator Eduard Lindeman wrote that the whole of life is learning therefore education can have no endings; Social scientists and psychologists defined variously the concept of learning; some of sect psychologists define learning as a product of outcomes ${ }^{3}$. This is similar to the museums' role today where museums in many countries are dedicating themselves for lifelong learning for all their audiences. museums' role today where museums in many countries are dedicating themselves for lifelong learning for all their audiences.
Additionally, museums can play a vital role in the development of society by presenting certain ideas and values. Museums are even important centers of information and knowledge. However, for the public, museums have been defined as cultural institutions, important centers of information and knowledge. However, for the public, museums have been defined as cultural institutions, for education and enjoyment ${ }^{2}$. Learning in museums is potentially dynamic and profound, producing self-identities. '. Learning
is part of the museums' perspectives to change an individual's knowledge, skills, attitudes, beliefs, feelings, and concepts. is part of the museums perspectives to change an individual 's knowledge, skills, attitudes, beliefs, feelings, and concepts.
Humanistic education means that the ideas of the humanistic psychologist are the development of approaches to adult basic education. Proper believes that human beings have natural needs to learn and that good education is therefore to help people develop their life potential. It's essential to ensure that young people progress successfully from basic to advanced literacy develop their life potential. It's essential to ensure that young people progress successfully from basic to advanced literacy
skills and raise advanced literacy skills for all society? the society and they activate their collections to serve their vision and missions. Museums overcome challenges for competing with other institutions and associations through adults' literacy programs. Working together with people with different skills, experiences and backgrounds are difficult and time consuming; but it always results in creative work when we provide a progran which creates opportunities for positive socializing and peer support, sharing and exchanging skills. Sometimes it is making individual and collective decisions, a sense of contribution and achievement $t^{8}$. The priorities are breaking the link between poor literacy levels and deprivation. One of the main approaches is to improve the skills of the few who have difficulties with basic literacy, particularly those who are vulnerable. There are some points of focus that museums should put in consideration such as, motivation, communication/contact, spaces, channels, strategies, language, interpretation and the experience factor. Conducting a style of exhibitions which are relevant for illiterate adults makes a connection between the exhibition and the interests, memories and experiences of the community. The value of an artifact or collection is never limited in its historical or artistic value; its value also lies in its ability to tell stories and to relate to people. ${ }^{9}$ Museums are designed for learning; museums embody views about what's worth learning, and the way that artworks, objects, and historical material are presented. A number of key factors are worthy of consideration by museums in their capacities as lifelong learning entities, and ideal centers for self-directed learning. Going through what museums can offer to Adults' literacy, they should focus on "Lifelong learning" or "Learning society" term which is the term indicating that learning does not stop at childhood since many adults engage in informal and formal learning for different reasons. ${ }^{.0}$ Museums are, in many countries, dedicated themselves for lifelong learning for all their audiences including school students, universities, groups, and adults (Lifelong learning European program 2012 2014). They use galleries, exhibitions, workshops, courses, lectures, and outreach programs to enable the visit to the museum. More recently, museums have again taken on an educational function, for adult learners as well as school students. ${ }^{1}$ Still some museums are trying to give the best educational role in an awkward sitting. Museums as learning institutions need to conside the implications of what lifelong learning means in a practical sense, such as an obligation to advance their own lifelong learning procedures.

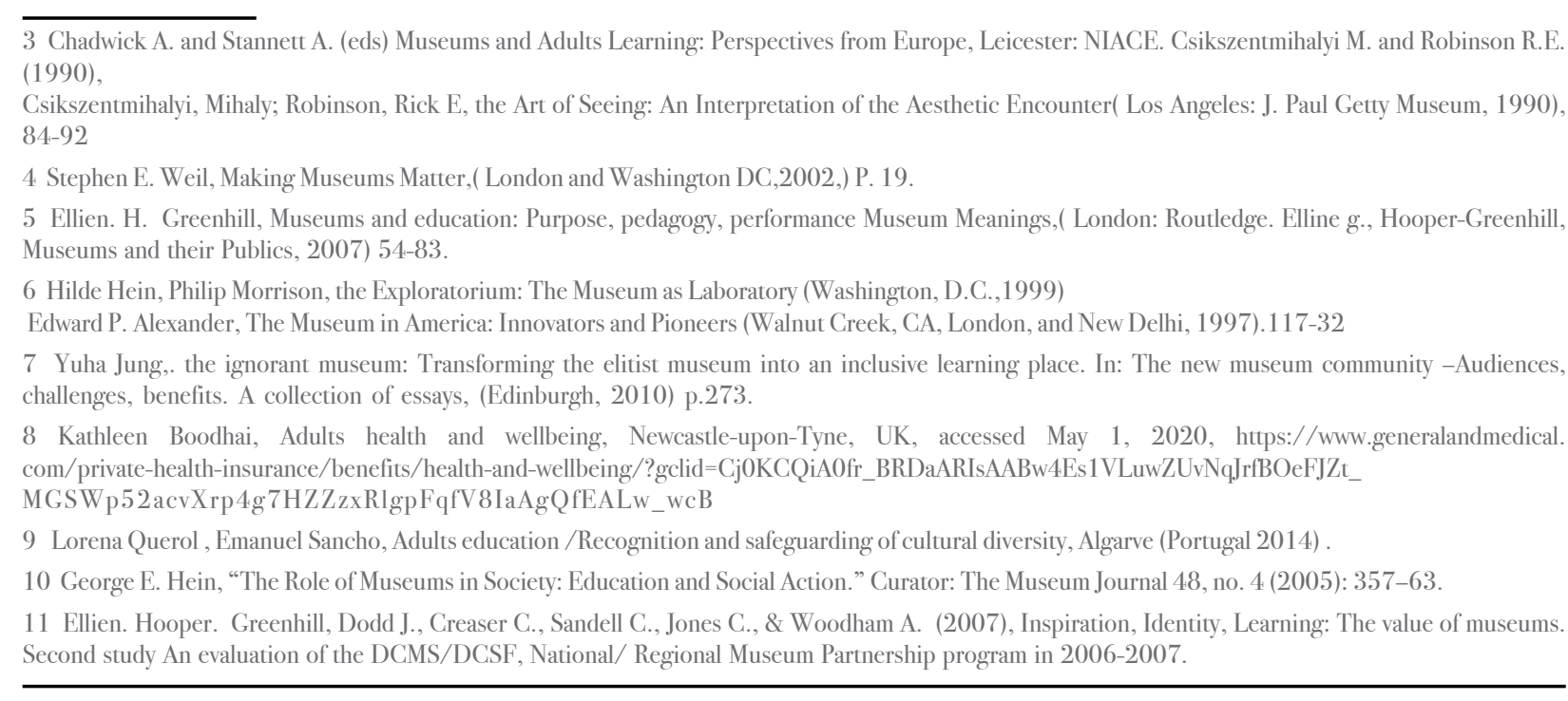




\section{Adult literacy}

Adult learning has been peripheral in museums; museum lifelong learning has been peripheral in adult education. What can museums offer to the adults' literacy? Why adults' literacy doing more learning? Learning experience! How far can museums add value with its collections, stories, spaces for adult literacy? ${ }^{2}$ Knowledge and skills are vital for the effective organization of adult literacy work. Ideally, the learning environment should be proper for their needs at any given time. The Modern museums are trying to acknowledge how museums can support this case by removing barriers to access adults' literacy programs through innovative projects and collaboration with communities. Museums' ability to weave narratives and suggest inferences allows
it to act as a base for reflection on knowledge systems, beliefs, values and attitudes. Museums are friendly environment and dialogue places for all ages, from all social levels and cultures, whether educated or illiterate. More recently, museums have again taken on an educational function, for adult learners as well as school students

\section{Museums' role in the sphere of adults' literacy}

Museums should consider the guidelines for good adult literacy which involve listening, speaking, reading, writing, numeracy, and using everyday technology to communicate and handle information (NALAS vision 2012). It could be defined also as involving multiple modes of visual, gestural, spatial and other forms of representation ${ }^{14}$. Touching, smelling, and using the objects can be the museums tools to educate illiterate adults. Actually many of the theories that literacy scholars depend on especially in their work emerge from socio-cultural perspectives. ${ }^{15}$ However, socio-cultural and socio-linguistic theories on literacy development and practice have been influential for decades. Museums today should address the Four pillars that are the answers why the adults learning; to do, to know, to live together, and to be ${ }^{16}$. To do: some of the adult are looking to evaluate themselves in their old job by learning biotechnology, people skills, increasing language, literacy and numeracy demands in the workplace. To know: most people learn for learning, rather than due to knowledge being a tool to achieve practical outcome. To live together: subjects need to discuss and learn such as human right, sustainability, and peace, aboriginal in order to live democracy multicultural. To be: we learn to leel personal, physical, spiritual development and enrichment. ${ }^{7}$ (Thus, museums should offer a variety of programs for visitors of all ages that vary between targeting literate and illiterate ones, creating programs tailored to the specific needs of all the visitors and presenting powerful educational experience that meets the goals, prospective and massage of the museum. Museums face many challenges today in terms of meeting the lifelong learning environment. The challenges are to maintain and strengthen museum curriculum and development processes that are critically aware, flexible, responding, learning-centered and learner-directed through the museums. The task of creating a rich literate environment, however; requests greater challenges and responsibilities in communities with a large number of illiterates and neo-literates ${ }^{18}$. New technology and globalization drive adult literacy by necessity or choice to learn new skills, knowledge and attitudes. Other challenges are to deconstruct/dismount the traditional view of museums as elitist places and to build a socially committed Museology, turning museums to be useful places for the population ${ }^{19}$. Museums should consider what is the museum's overall mission in regards to adults' literacy, How to attract illiterate adults to museums and how will the success be defined? Museums possess the sufficient cultural of capital for decoding and appreciating complex cultural.

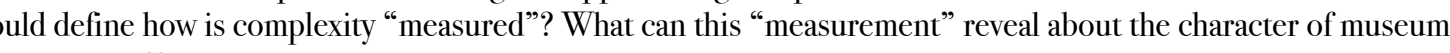
that's based on learning ${ }^{20}$; the museums' professionals should consider the real meaning of Literacy; Literacy leads to the

$\overline{12}$ John H. Falk, Lynn D. Dierking.. Learning from Museums: Visitor Experiences and the Making of Meaning, (Walnut Creek, CA: AltaMira Press, 2000 13 Elena Delgado, Museums as spaces of negotiation, Museums as places for intercultural dialogue: selected practices from Europe, (British museum. 2009 . P8-9.

14 Kristen H. Perry, What is Literacy? A Critical Overview, Journal of language and literacy education 2012).P2-26

15 Marjorie Mayo, Jane Thompson, Adult learning, critical Intelligence and social change, NIACE,, Leicester, UK, 1995)

16 UNICCO report Delors, Rethinking education and learning, accessed May 1, 2020, https://en.unesco.org/themes/education/research-foresight/ evisiting-learning

17 Jo Graham, engaging adult audiences, Delegate pack extra materials from course, accessed May 1, 2020, https://abcofiworkingwithschools.files. (106/engaging-adult-audiences.pd

18 ICOMOS International Tourism Committee, International Cultural Tourism Charter, accessed Mav 1, 2020, https://www.icomos.orrg/charters/

. Nikki Lindsey, Audience Champion, Historic Royal Palaces, Intergenerational Adults and children, (United Kingdom 2014). progressing of all education goals. ${ }^{21}$

It is also considered to be a matter of poverty reduction. It is the ability to identify, understand, interpret, create, communicate, and compute using printed and written materials associated with varying contexts ${ }^{22}$. While it effects economic development 列 to have voice in society: to continue and extend their education: to read and to be. Although literacy is an important part of everyday life, individuals vary greatly in their purposes for reading and writing. ${ }^{23}$

the adult literacy is widely interpreted. One of it is the educated adults with the lack of technology or science experience and aspiring to learn them. Another one is the illiterate adults; with low education skills from all ages, all types of community and with many different backgrounds, lifestyle and experiences ${ }^{24}$. However, those adults are talented in the workplace and social relationships. There are some European museums' efforts under the title "lifelong learning" programs 2008-2010, which inditered to addit literacy meaning lack of visitors with low income. Literacy is something that one either has or does not have; people are not elaborate the process of how poope who are illiterate are deficient. Although the theory of literacy as social practice order to activate literacy practice engeople learn to read and write, it probably into ns what types of knowledge needed in Orlf

An adult literacy learner must have missed, for one reason or another, the opportunity of learning how to read, write and count numbers at his or her appropriate younger age. Some of them try to acquire such fundamental skills in his or her adult years ${ }^{26}$. Adult and non-formal education programs generally provide basic, functional and post literacy. Those are for disables, blind women, workers and others ${ }^{27}$. Given the lifelong learning objectives of adult education, most third world countries use adult education to improve literacy, to upgrade occupational competencies, and for community development. Museums can be used for both individuals and group learning in informal and formal structured courses ${ }^{28}$

Thus, the role of museums today is to develop literacy skills, which will help people to improve their circumstances and that of their families and communities. The museums programs should consider the various definitions of literacy that associsted wit different areas of life and based on a philosophy of adult education; many countries discovered that literacy skils enate wit citizen to engage effectively and fully in society, to use services, to communicate and to express and share ideas. One of the idea that could face such challenges is the storytelling programs which can support literacy development, curiosity, motivation to learn across a curriculum.

A good storyteller can engage interests and enthusiasm for a range of subjects such as religious studies, history, geography, language, literature and drama. Storytelling can be for changing behavior and expanding people emotional attitude. A key feature of an exhibition experience is the storytelling delivered by well woven narratives by storytellers $\mathrm{s}^{29}$. Therefore, the challenges could be to address what museums aim with their role for adult literacy? How does adult literacy describe learning the place of learning in their lives and where the museum situated? How illiterate adults describe themselves as learners withi socio-cultural context, including their future views of learning and the roles learning play in their lives ${ }^{30}$.

Learning new things in all life stages open the minds and give us the opportunity to develop personal confidence. Learning provides several tools for managing technological and industrial change; it helps the learner explore several ideas, thoughts, and innovation. While learning has a deep social impact enabling one to deal with the "risk community", lifelong learning has many benefits on individuals, businesses, and communities.

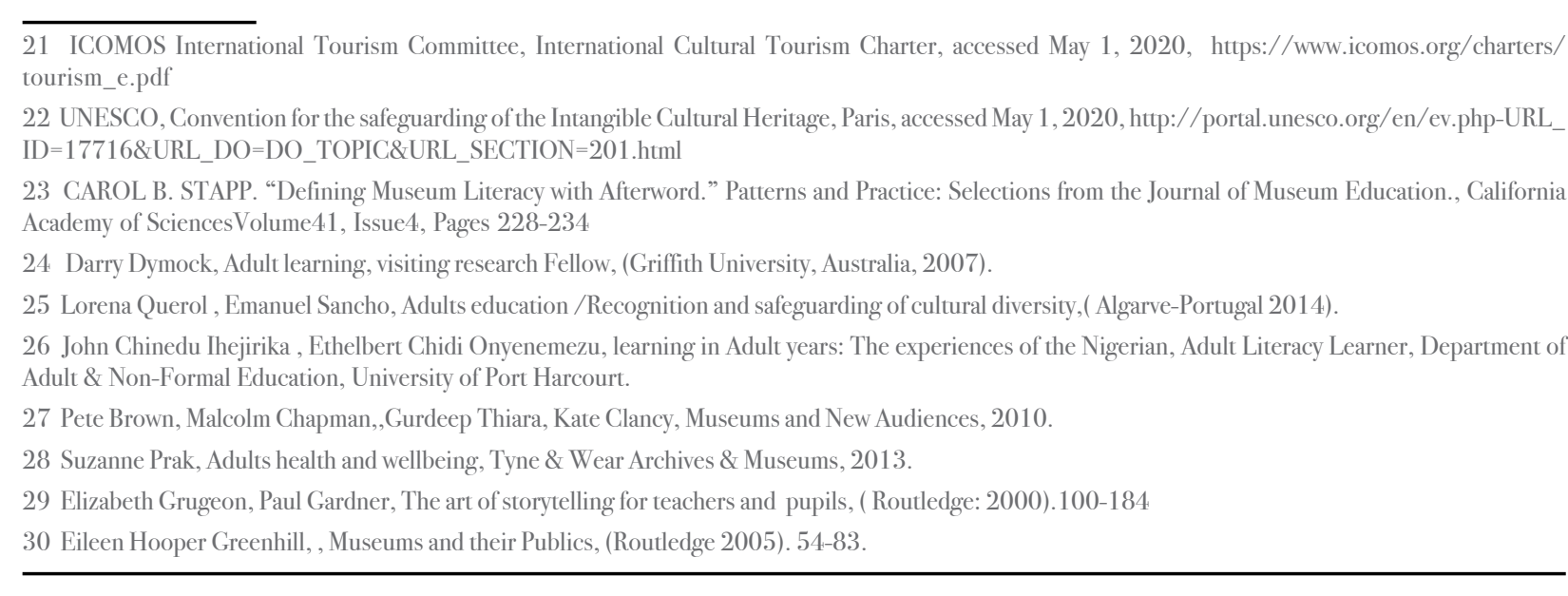




\section{Museums activities and workshops for lifelong learning for Adults}

The Coptic Museum presented several educational programs in 2014 to raise cultural heritage awareness which became sustainable programs for all Egyptian museums. "Fic.1 ". The programs included lectures with varied topics, for example, by practical workshops to explore the participants' skills. In 2016, the Egyptian Museums such as Coptic, Islamic and Gair by practical workshops to explore the participants' skills. In 2016, the Egyptian Museums such as Coptic, Islamic and Gair One of the museums educational programs was to train unemploved women from the local community in different crafts. These were carried out cooperation with the Rasayil Adam and other NGOS Foundations. In addition, the main target of this program was to engage different assortments of Egyptian community and inspiring them through the cultural Heritage presented in museums; especially giving stories behind the intangible aspect of tangible heritage.

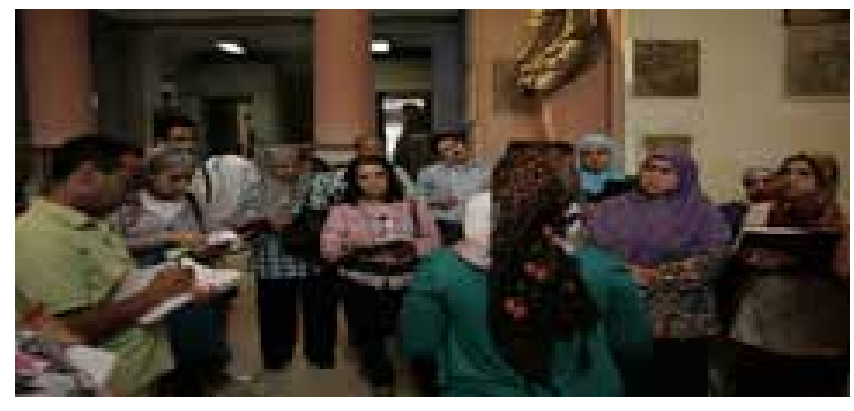

Fig. 1.: the photo shous sthe participants listening to the Researcher. (Photo by the Museum Education Department 2016).

Those programs aimed to tackle one of the community's problems, namely financial challenges and unemployment of women. Unemployed girls and women took part in several seminars to produce crafts, using the Museums' collections such as textiles, jewelry, pottery and glass for inspiration. "Fig: 2 "

The Nusenur's curators and educators cooperated with artists and crafts specialists in training the wong in traditional crafts.

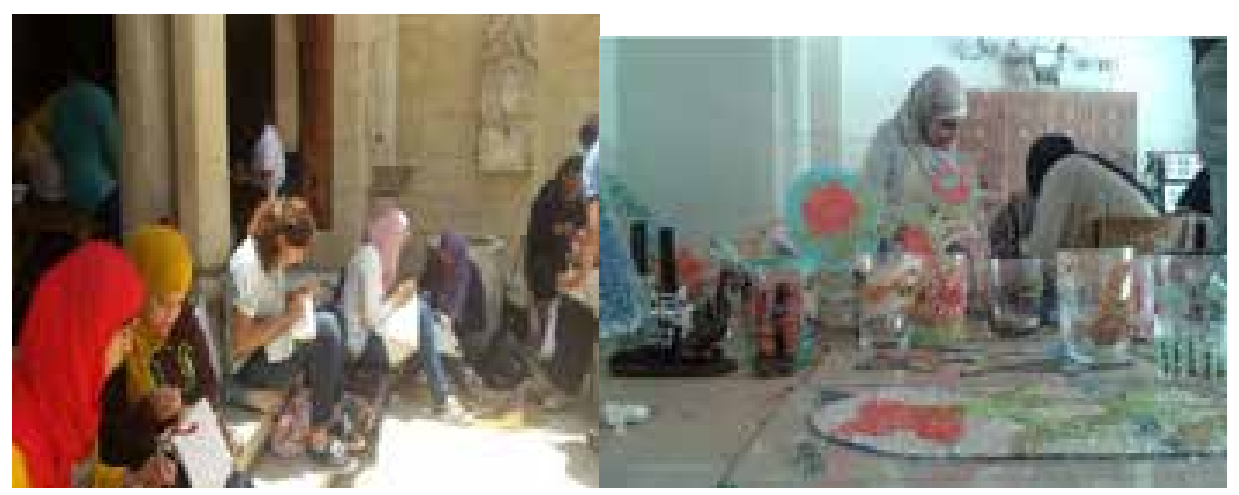

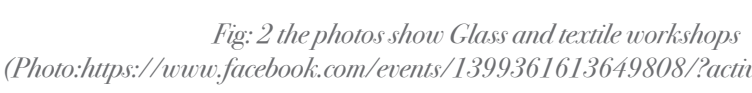

The trainers brought with them the materials and tools. The Ministry of Trade and Industry funded the workshops to encourage the Coptic and Islamic Museums in cause for community development.

Participants were very hard working, and proved that women can share in hard jobs, especially the alabaster workshop. "FIG: 4 (aved cert if icat esf romtheHead of theMuseums' Sect or, whichthey very mork the last day of the workshop. "Fic.3"

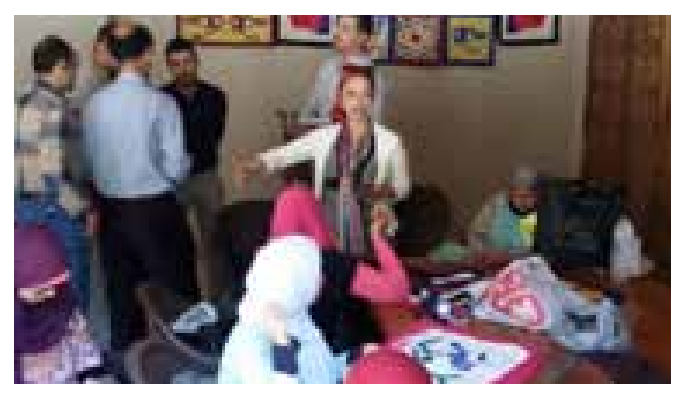

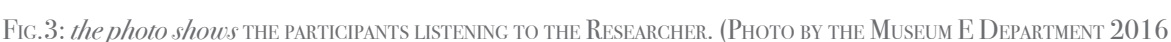

Questionnaires were distributed amongst the participants. The results show that almost $90 \%$ loved the workshops and the Coptic and Islamic Museums. About $70 \%$ enjoyed having lectures inside the galleries and were inspired by the collections. Some participants even request to extend the workshops.

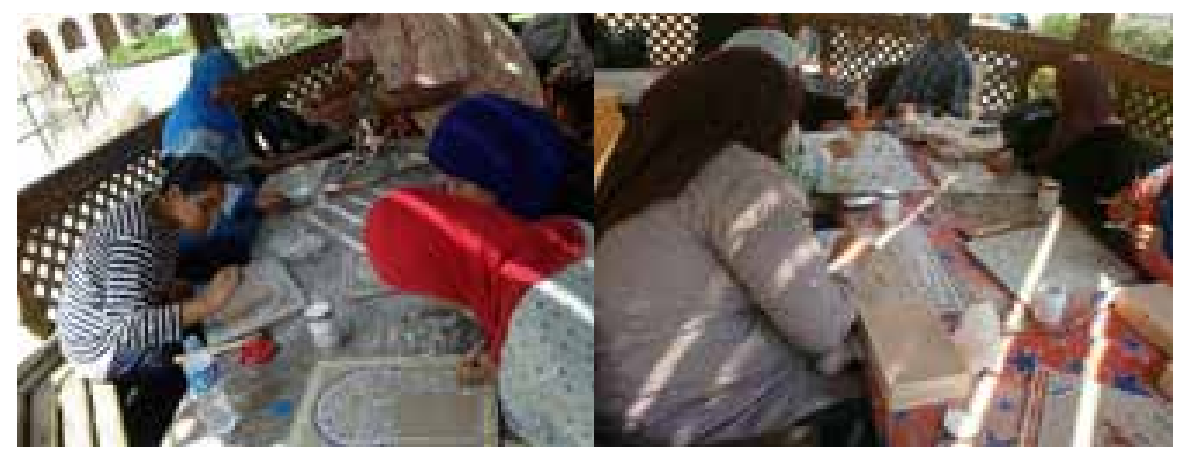

Fic: 4 the phot os show Mosal WORKSHOPS. (PHoTO BY E. SALAH 2016)

Sohag museum programs and workshops of lifelong learning for Adults

Learning new things in all life stages gets the mind going, gives us the opportunity to develop personal confidence. Learning provides several tools for managing technological and industrial change; it helps the learner to explore several ideas, thoughts, and innovation, while learning has a deep impact socially, enabling the one to deal with the "risk community", lifelong learning has many benefits on individuals, businesses, and communities.

The general optimism of teachers about the outcomes of the visit to Sohag museum becomes very evident upon reviewing the positive responses as a whole. In discussion with teachers, it was clear that the teachers saw pleasurable experiences as central to effective learning and a great opportunity for those who visit the museum to generate enjoyment.

Sohag Museum presented a series of special lifelong learning programs for Adults in co-operation with civil society association s and the context of activating the role of the Museum as educational and cultural institution for other community development workshops. The program "Accepting the other unconditionally" was held on and delivered by Basma Attia, a specialist in psychological counseling, at the museum's headquarters for volunteers, to accept others without any conditions, whether gender, culture or religion.

The target group of the educational program: public in general especially adults

Participating: Museum participants

Time frame of the program: The program i $\backslash \backslash$ son Tuesday 18/9/2018. The program was held weekly on Tuesday with participating group from nine o'clock until noon

\section{The goal of the educational program}

The concept of lifelong learning is a paradoxical concept. On one hand, they are self-evidently related to positive ideas of progress and democracy for all citizens, regardless of their social status and cultural imperfections. On the other hand, they tend to 


\section{Those who implement programs}

museum educators, volunteers and curators

In the global market of the Nordic countries, lifelong learning is seen as an additional development of popular enlightenment, linked to democratic social ideas about welfare and equal opportunity. Several Adult educational presentations, such as, evening schools, summer schools, open institutes, colleges etc, highlight the position of the Nordic countries as a prominent place in international statistics of adult education. Additionally, the field of education becomes one of employability, to increase personal flexibility in accordance with the ever-changing demands of the workforce in the so called "knowledge society" In the field of museum education, we could say that learning in museums is traditionally associated with the "soft" human ideals of lifelong learning; such ideals, identify popular enlightenment, personal development and active citizenship, similar to those of Scandinavian youth. Museums and exhibition galleries must offer more than interesting presentations; they should be able to communicate these ideas and themes with the life experiences of different groups of audiences, they should be able to build community outreach

\section{Sohag Museum}

presented a series of special lifelong learning programs for adults in co-operation with civil society associations.

\section{The target group of the educational program}

public in general especially adults

\section{Participating}

Museum participants

\section{The goal of the educational program}

(Learning can be a powerful agent in) combating social exclusion by giving people the abilities, skills and confidence to be involved in society. Through the celebration, there was a series of community issues affecting Sohag society, so they were discussed in the lectures Hall of the museum, and the program included:

* Theatrical presentation titled "The sweetness of the generator " composed, acted and directed by volunteers 10-10.30 Am

* Lecture on: kings, wars, treaties and peace charters throughout the ages (through a presentation by volunteers) 10.30:11.00 AM

* Lecture on Unconditional acceptance: self acceptance.. acceptance by Mrs. Basma Attia, specialist in Psychology counseling, from $11.00: 12: 00 \mathrm{pm}$

Time frame of the program: Opening (9-9.30 am)-Screening of volunteers ‘ achievements during the previous period 9.30 $-10.00$

Those who implement programs: museum educators, volunteers and curators

The museum education policy can provide a resource for the learners; that resource might help learners studying in both formal and informal education where museums are a public place for learning and entertainment. Those are combined and act as one unit; museums can encourage adults who are seeking formal education, such as audience of museums who might be afraid of taking the first step towards lifelong learning. In addition, museums can provide an environment full of inspiration, curiosity and creative thinking. Any museum needs to provide a talent base for several creative industries, media, performing arts, film, and design. Museums themselves are centers of creativity where their collections are often designed and exhibited by specialists. Sohagmuseum presented a series of special lifelong learning programs for adults in co-operation with civil society associations. The programs title: Learning how to act: This was a special program that aimed to attract young generation and teach them how to present plays of ancient Egyptian. Other programs were on psychological counseling provided by specialists on unconditional acceptance.
The target group of the educational program: public in general especially adults Participants: Museum participants

The goal of the educational program: Learning style depended on how learners prefer to get information and the differen types of learning Learning style is also affected by left and right side brain dominance. Specialists have identified that our brain are divided into two connected hemispheres. The left side activates processing information in an analytical, rational logica and sequential way. The right recognizes relationships, integrates and synthesizes information and arrives at intuitive insights. Time frame of the program: Opening address (9-9.30 am)-Screening of volunteers' achievements during the previous period $9.30-10.00$ break 11.00 am to $12 \mathrm{pm}$

Those who implement programs: museum educators, volunteers and curators

The Sohag museum planned several programs for adults in cooperation with the general authority for literacy and lifelong learning for adults. "FIG: 5 "

On the $4^{\text {th }}$ of September, a group of members of Sohag museum's education, Public relation and curators' departments visited the General Governmental Association of Literacy and Adult education in Sohag. The aim of the visit was to manage a protoco of cooperation between Sohag museum and the association by setting several workshops and activities on literacy.

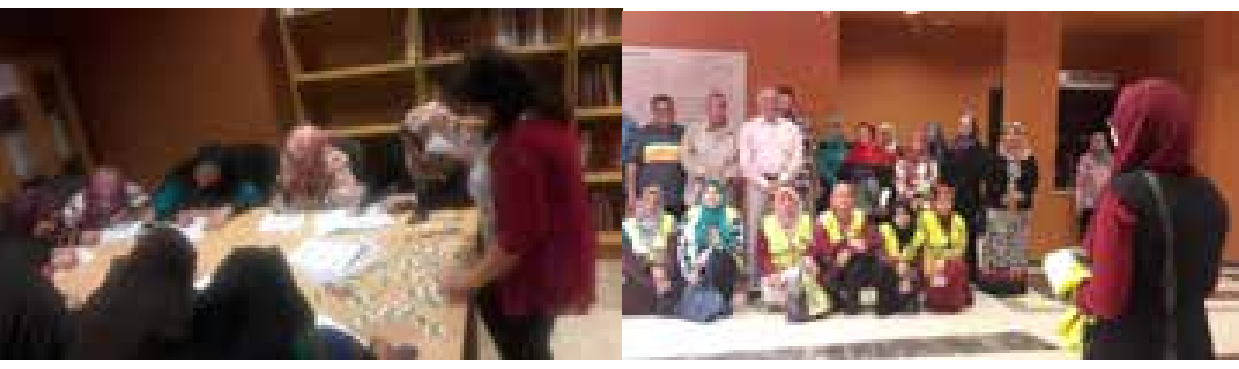

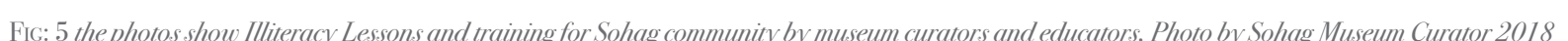

The idea of learning in the community utilizes the sense of social cohesion and empowers the economy. Sohag museum had long programs for lifelong learning for Adults in cooperation with civil society associations.

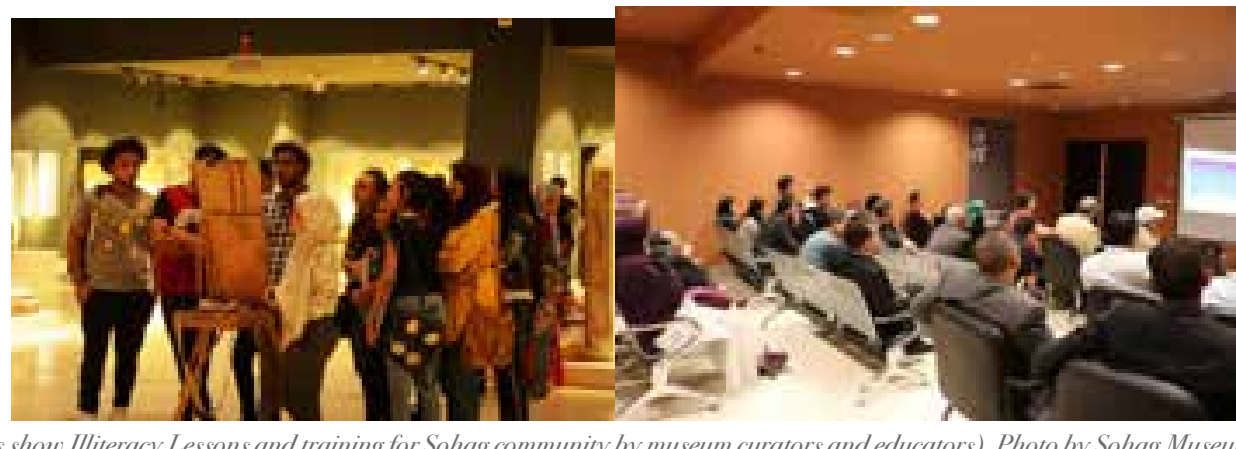

In the context of activating the role of the Museum as educational and cultural institution for community development, another workshop entitled "Accepting the other unconditionally" was held on Tuesday 18/9/2018. It was delivered by Basma Attia who is specialist in psychological counseling, at the museum's headquarters for volunteers, to accept others without an condito whe On one hand, hey a derf status and cultural imperfections. While on the other hand they about how Western 


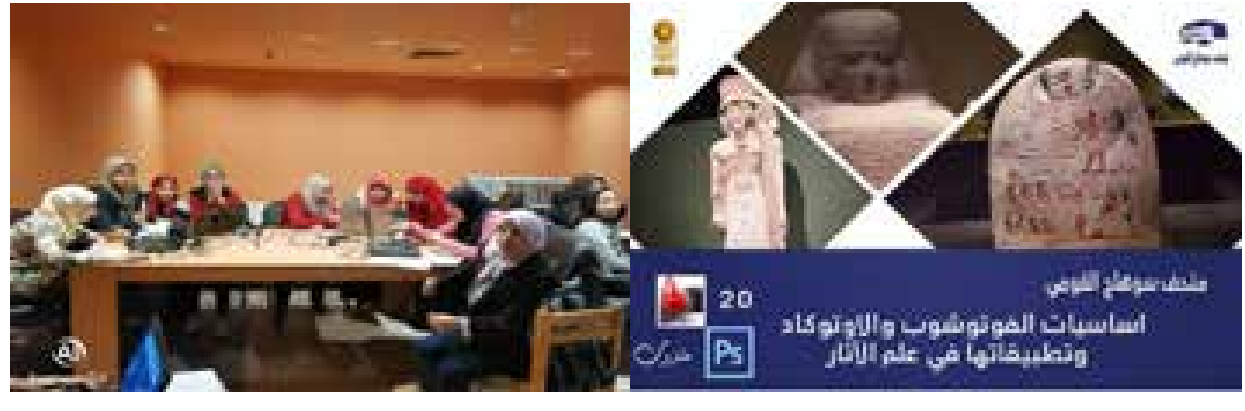

Fig: 7 the photos show Lifelong learning for Adults" "CCT workshops on Photoshop by specialist" in Sohag. Photo by Sohag Museum Curator 2019.

Societies face competition. In the Global market of the Nordic countries, lifelong learning is seen as an additional development of popular enlightenment, linked to democratic social ideas about wellare and equal opportunity. Several Adult educational presentations, such as, evening schools, summer schools, open institutes, colleges etc, highlight the position of the Nordic countries as a prominent place in international statistics of adult education, and The field of education becomes one of employability: to increase personal flexibility in accordance with the ever-changing demands of the workforce in the so-called "knowledge society".

Sohag museum programs for Adults were various to develop their ways of thinking and behavior, so one of the workshops was in cooperator whith was on "Photoshop and AUTOCAD" basics and their application to archaeology. Thirty two participants of graduated and undergraduate students males and females joined in the workshops and they stated that the workshop was very helpful for their studies. The workshops were free and that encouraged the participants to be very serious, active and motivated.

The target group of the educational program: Adults

Participating: 100 participants

The goal of the educational program: The workshops aimed to give opportunities for the participants to find chance for job opportunities especially that technology became the essence of life. The trainer was also happy to deal with and he commented that he feels something different because of the atmosphere; it is a museum lap not a company lap which was really impressive and very progressing for museum field. it is the impact of the lifelong learning programs which converted the museum to be a field of everything in life and connected past, present and future. It makes the museum interesting and lively (Fig: 7).

Time frame of the program: A month, which started from 1/8/2019 till 30/8/2019 at 10:00 am break at 11.00 am to 4.00 pm. The day was divided into two parts the first part was a lecture with the Academy trainer in the lecture hall then the other part was a guided tour in the galleries

* Those who implement programs: museum educators, volunteers and curators

\section{Conclusion}

The museum offers considerable learning potential collections exhibited, providing pupils with intangible connection with time, places, events, or people and allowing them to experience the evolution of the Upper Egypt history and cultural heritage. The display helps pupils understand the historical value of objects; the programs of the museum give students the ability to engage actively in the process of acquiring knowledge and to express thoughts and emotions.

- Students number in total 125 .

- Some of them stated that they didn't visit the museum before, although they mentioned some of their most attractive objects, which means that they are following the museum page on social media. workshops participants questionars 2018

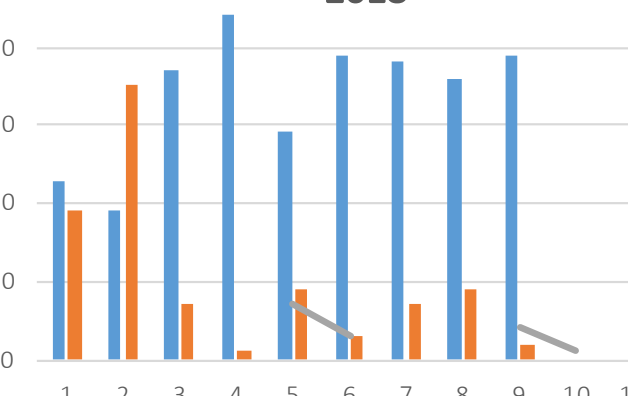

yes no

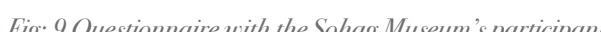

\section{Conclusion}

To sum up, the conception of "lifelong learning in museums" has increasingly attained great importance where the museum as an educational institute of the integrated lifelong learning system has to provide a satisfactory environment to achieve the goals of the museum lifelong learning especially for adults' literacy dimensions. One of the main priorities is eradicating cultural and functional literacy as well as setting adult literacy programs as part of museums educational roles and communication with new methods as a matter of the changing roles and goals of museums through the last decades. Learning provides the tools for technological and industrial changes; it enables the learner to explore several ideas, thoughts, and innovation. It also has a deep social impact where the learner deals with the community risks and benefits from the lifelong learning experience whether in business or in dealing with the community. The idea of learning in the community utilizes the sense of social cohesion and empowers the economy. We provide participants with an overview of what to expect at galleries. An introductory panel wit a map and marked routes is explaining practical aspects of a guided tour mind your head, don't touch the stalagmites etc.

introducing the theme and how the talk will progress.
The museum should consider the interaction with the objects and its interpretation, the creation of the visitors' interpretation and experience, in addition to making and testing their other hypotheses and evaluating the museums display. The museum should address the illiterate adults" needs and interests. Moreover; the mission and the vision of museum should address the lifelong learning dimensions. Educational programs of museums should support people to develop positive life, change the help to give their lives more meaning. Special educational programs especially on traditional crafts learning aspects can be museum learning material tool for both illiterate men and women; especially those who have handmade skills and this can help them to gain more experience and improve their financial resources as well. Museums can set up special proorams with the minority group of handicrafts who had never visited a museum before as a strategy to engage them with the museum. In addition museums' gift shops can offer spaces for selling their products. The museum's objective is to provide an environment that is capable of directing, correcting the sinuous path of man's life, and enabling the man distinguishing between right and wrong to reach the nominal and the highest level of humanity. Museums could improve one's behavior, direct attitudes such as no spitting, no jamming, no eating or drinking, no dirty shoes, and no gambling as effective approaches in such behavioral change. The museums as "learning centers" provide the public with a range of educational programs according to individual interests and needs. Museum and today's young people seem to accept the fact that education is an individual issue involving all aspects of a learner's personality. These kinds of workshops through the museum galleries can build acknowledge and transform experiences enhancing the skills that are nowadays rare or almost forgotten. Transformative literacy merges thoughts and feelings of people leading them to think, fecl and act responsibly. Engagentent inc creative and craft workshops and touching museums" objects inspired aeshetic skills, a learning by doing approach. Museums and adth edcation entities combined should find their aspirations coinciding with government's social policy initiatives and, with the policies of other funding agencies. Finally, museums today should connect communities, lifelong learning, democratic values and intergenerationa learning. 